\title{
Rare variant of internal carotid artery anatomy
}

\author{
Ankita Aggarwal, ${ }^{1}$ Parveen Gulati, ${ }^{2}$ Kanwaljeet Garg ${ }^{3}$
}

${ }^{1}$ Radiodiagnosis, All India Institute of Medical Sciences, New Delhi, India

${ }^{2}$ Radiodiagnosis, Doctor Gulati Imaging Institute, New Delhi, India

${ }^{3}$ Neurosurgery, All India Institute of Medical Sciences, New Delhi, India

\section{Correspondence to Dr Kanwaljeet Garg, gargneuro@hotmail.com}

Accepted 29 December 2018

\section{DESCRIPTION}

A 77-year-old woman presented with history of repeated transient ischaemic attacks.

She did not have any neurological deficit. MRI scan of the brain with Magnetic resonance angiography of neck and brain was done. A rare variant of carotid anatomy was noticed (figures 1 and 2). Her right sided internal carotid artery (ICA) terminated abruptly at $\mathrm{C} 2$ vertebral level distal to its origin from common carotid artery (CCA) at C4 level. A branch arising from the external carotid artery (ECA) at C2 level continued into the head instead. The left sided CCA was normally branching into ICA and ECA at C4 level. The described variant of ICA arising from ECA with a proximal ICA stump is an extremely rare variant.

CCA arises from brachiocephalic trunk on the right side and as a direct branch of aorta on the left side. It ascends vertically in the neck, and divides into ICA (posterolateral) and ECA (anteromedial) at the level of C2-C3. ECA gives multiple branches in the cervical and facial region, whereas ICA does not have any extracranial branch. Few reports in the literature have described the entity non-bifurcating CCA (NBCCA), wherein there is anomalous ICA-ECA anastomosis, however these cases do not have a proximal ICA stump as in our case. ${ }^{12}$

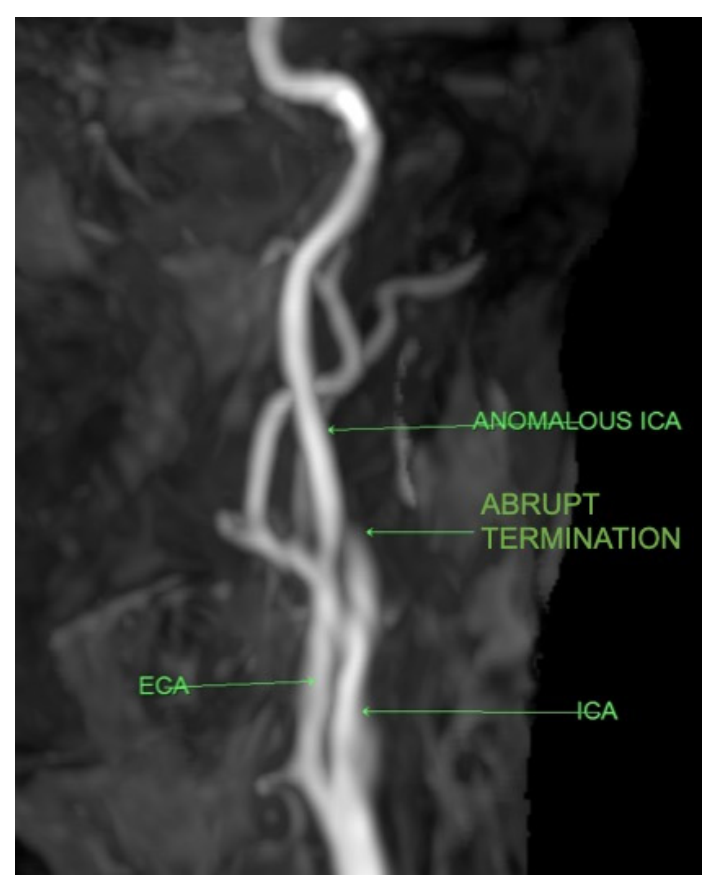

Figure 1 Three-dimensional maximum intensity projection (MIP) image shows abrupt termination of cervical internal carotid artery (ICA) with a branch of external carotid artery (ECA) coursing in the distal expected course of ICA.

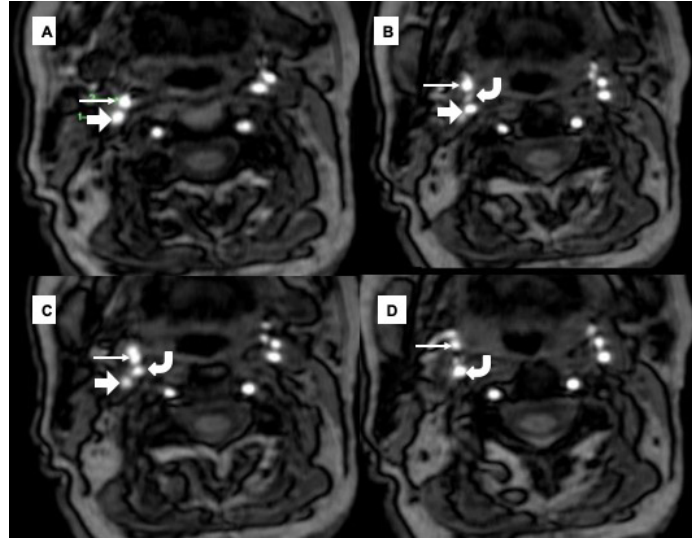

Figure 2 Magnetic resonance angiography time of flight. (A) External carotid artery (ECA) (thin arrow) and internal carotid artery (ICA) (thick arrow) after bifurcation, (B) branch arising from ECA (curved arrow) can be seen between ECA and ICA (which gets further narrowed), (C) ICA gets narrowed as it courses cranially, (D) the branch arising from ECA continues along the course of ICA and ICA is not seen.

Embryologically, it is the third aortic arch which gives rise to ICA and then continues as dorsal root whereas ECA arises from ventral aspect of third aortic arch. The likely hypothesis for development of NBCCA is due to persistence of hyoid-stapedial artery which leads to formation of this anastomosis. Congenital absence of the ECA has been reported in literature. ${ }^{3}$

Professor Lasjaunias in his article proposed segmental concept of carotid artery-which states that ICA results from persistence of several embryologically different segments (ventral pharyngeal hyoid, mandibular, primitive maxillary, trigeminal, dorsal ophthalmic and ventral ophthalmic). ${ }^{4} \mathrm{He}$ further stated that each segment may undergo agenesis independently and blood flow is established through the ICA distal to the agenetic segment. The abnormality in this case may result from agenesis

Learning points

- In our case, internal carotid artery (ICA) terminated abruptly at C2 vertebral level and a branch arising from the external carotid artery (ECA) at C2 level continued into the head instead.

- In non-bifurcating common carotid artery, there is anomalous ICA-ECA anastomosis, however these cases do not have a proximal ICA stump.

- It is important for both the radiologist and neurosurgeons to be aware of this anomaly. 
or dysgenesis of proximal cervical ICA and reconstruction from persistent proatlantal artery.

It is important to have a complete knowledge of the anatomy of carotid vessels for planning any intervention. It is important for both the radiologist and neurosurgeons to be aware of this anomaly. For a radiologist, it is important while doing endovascular intervention as such an anatomy can be confusing. It is very important for surgeons to be aware of this rare variant as ICA is exposed in many surgeries like carotid endarterectomy and ECA-ICA bypass.

Contributors AA: Writing manuscript. PG: Revising manuscript. KG: Writing manuscript.

Funding The authors received no specific grant for this research from any funding agency in the public, commercial or not-for-profit sectors.
Competing interests None declared.

Patient consent for publication Parental/guardian consent obtained.

Provenance and peer review Not commissioned; externally peer reviewed.

\section{REFERENCES}

1 Ooigawa H, Nawashiro H, Fukui S, et al. Non-bifurcating cervical carotid artery. J Clin Neurosci 2006:13:944-7.

2 Nakai K, Kaji T, Uchino A, et al. Congenital external carotid-internal carotid artery anastomosis associated with contralateral non-bifurcating cervical carotid artery. Neuroradiology 2012;54:521-3.

3 Rodriguez HE, Ziauddin MF, Podbielski FJ, et al. Congenital absence of the external carotid artery: atherosclerosis without a bifurcation. J Vasc Surg 2002:35:573-5.

4 Lasjaunias P, Santoyo-Vazquez A. Segmental agenesis of the internal carotid artery: angiographic aspects with embryological discussion. Anat Clin 1984;6:133-41.

Copyright 2019 BMJ Publishing Group. All rights reserved. For permission to reuse any of this content visit

https://www.bmj.com/company/products-services/rights-and-licensing/permissions/

BMJ Case Report Fellows may re-use this article for personal use and teaching without any further permission.

Become a Fellow of BMJ Case Reports today and you can:

- Submit as many cases as you like

- Enjoy fast sympathetic peer review and rapid publication of accepted articles

- Access all the published articles

Re-use any of the published material for personal use and teaching without further permission

For information on Institutional Fellowships contact consortiasales@bmjgroup.com

Visit casereports.bmj.com for more articles like this and to become a Fellow 